\title{
Pengantar proteksi katodik
}

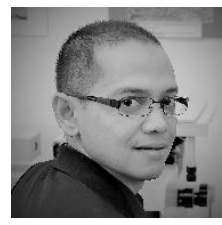

\author{
Hendra Hermawan, PhD \\ Associate Professor \\ Laval University, Canada \\ www.gmn.ulaval.ca
}

\section{Pendahuluan}

Tulisan ini merupakan pengantar pada bidang ilmu dan teknologi pengendalian korosi dengan proteksi katodik (cathodic protection, CP). Pembaca akan mendapatkan penjelasan singkat tentang dasar dan prinsip CP, penggunaannya dan faktor-faktor dalam pemilihan dan perancangan sistemnya. Untuk mendapat bahasan lebih mendalam atau bantuan konsultasi, pembaca dapat merujuk organisasi-organisasi yang dipaparkan di bagian akhir tulisan ini. Tulisan ini sebagian besar merujuk pada referensi 1.

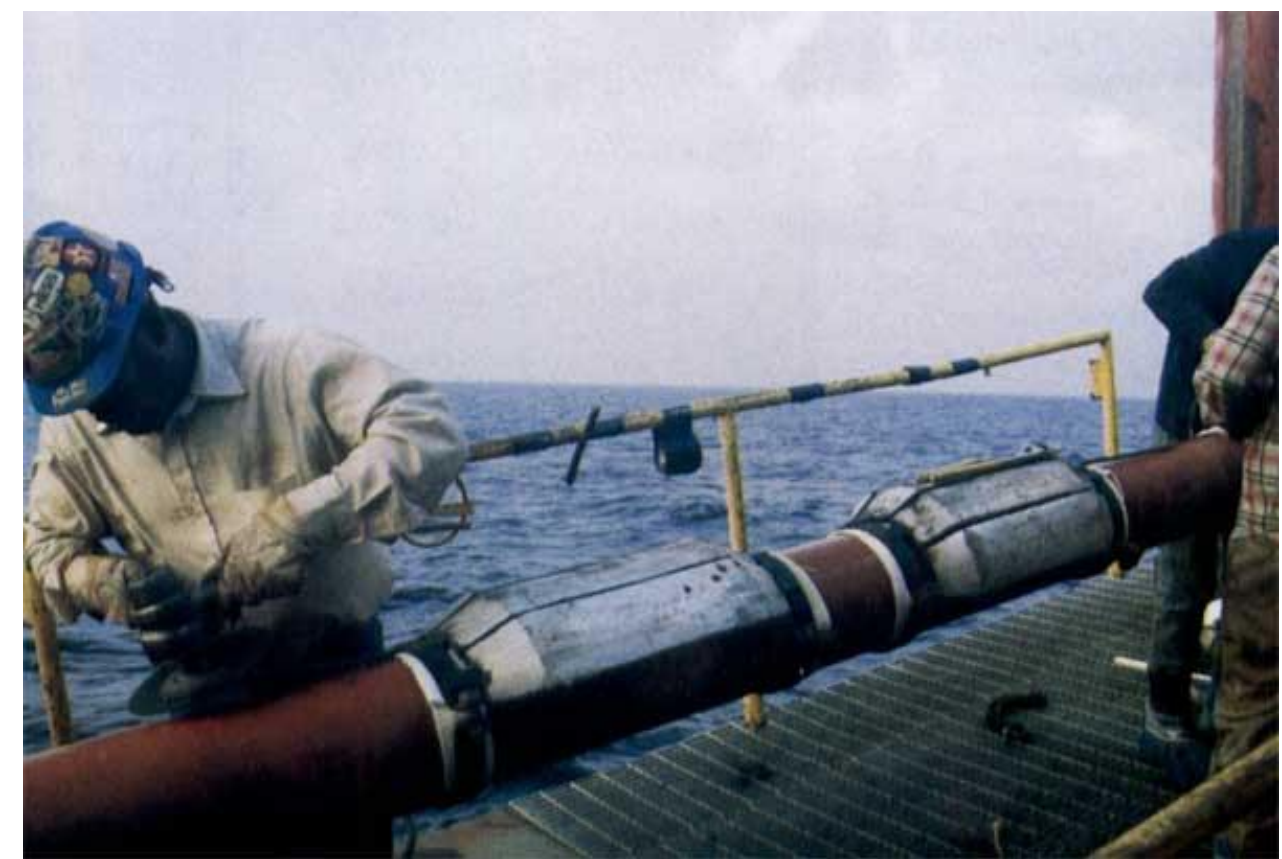

Gambar 1. Pemasangan sistim CP dengan anoda korban. Sumber: Deepwater Corrosion Sevices Ltd.

\section{Sejarah CP}

Orang yang secara umum dianggap sebagai pelopor penggunaan CP adalah Sir Humphrey Davy. Di tahun 1820an dia bekerja untuk Angkatan Laut Inggris yang menghadapi masalah korosi di lembar tembaga (Cu) pelapis lambung kapal-kapal Angkatan Laut. Davy menemukan bahwa Cu dapat terlindung dalam air laut dengan menempelkan lempeng besi ( $\mathrm{Fe})$ atau seng ( $\mathrm{Zn})$ atau timah (Sn). Tembaga menjadi, menurut istilah Davy, "terproteksi katodik". Namun penemuan ini ditinggalkan karena perlindungan $\mathrm{Cu}$ membuat sifat "antifouling"-nya menurun sehingga hewan dan tumbuhan laut tumbuh menempel dan menghambat laju kapal. 
Perkembangan CP secara pesat justru terjadi di Amerika Serikat setelah tahun 1945. Metoda CP menjadi mapan karena tuntutan dari perkembangan industri migas yang mengeksploitasi penggunaan pipa baja berdinding tipis untuk sistim transmisi bawah tanah.

Sementara di Inggris, pipa besi cor berdinding tebal dan bertekanan rendah lebih banyak dipakai sehingga CP tidak banyak diterapkan. Penerapannya meningkat setelah CP sukses digunakan untuk perlindungan jaringan pipa bahan bakar untuk keperluan perang sepanjang 1000 mil di awal tahun 1952.

Sekarang metoda CP telah cukup mapan dan digunakan secara luas untuk pengendalian korosi pada struktur and infrastruktur logam yang terendam atau terkubur atau juga untuk beton bertulang.

\section{Prinsip CP}

Logam yang telah diekstraksi dari bijihnya (kemasukan energi) memiliki kecenderungan alamiah untuk kembali ke keadaan awal (pelepasan energi) melalui reaksi dengan oksigen dan air. Kejadian ini disebut korosi dan contoh paling umum adalah pengkaratan baja.

Korosi adalah proses elektrokimia yang melibatkan aliran arus listrik dalam skala mikro dan makro. Perubahan dari logam (metalik) ke bentuk senyawa (ion atau gram terlarut) terjadi melalui reaksi anodik (Gambar 2):

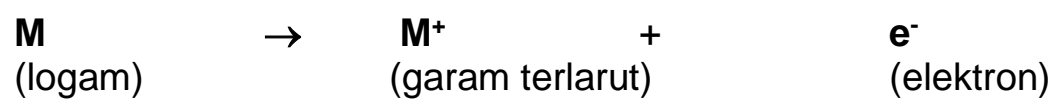

Contoh paling umum adalah:

\section{$\mathrm{Fe} \quad \rightarrow \mathrm{Fe}^{++}+2 \mathrm{e}^{-}$}

Reaksi diatas menghasilkan elektron bebas, yang mengalir dalam logam ke lokasi lain di permukaan logam (katoda), dimana dia dikonsumsi oleh reaksi katodik. Dalam larutan asam, reaksi katodik adalah:

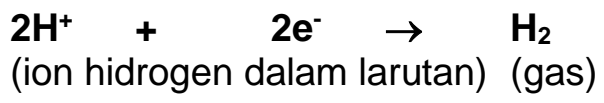

Dalam larutan netral, reaksi katodik juga melibatkan konsumsi oksigen terlarut:

$\mathrm{O}_{2}+\mathrm{H}_{2} \mathrm{O}+2 \mathrm{e}^{-} \rightarrow 4 \mathrm{OH}^{-}$

(basa)

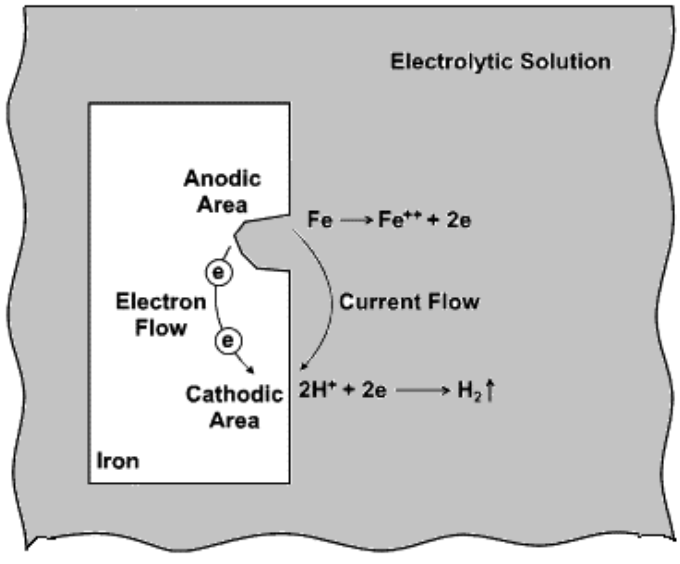

Gambar 2. Skema sebuah sel korosi.

Jadi, korosi terjadi di anoda dan tidak di katoda (kecuali logam di katoda diserang oleh basa). Anoda dan katoda dalam proses korosi dapat berupa dua logam yang berbeda yang terhubung satu sama lain, atau seperti yang terjadi pada baja yang berkarat, keduanya berdekatan di permukaan logam yang sama. 
Sebab awal terjadinya proses korosi berupa:

- Perbedaan potensial alamiah antara dua logam yang berbeda.

- Variasi kondisi metalurgi di permukaan logam.

- Perbedaan kondisi lokal lingkungan, seperti variasi oksigen di permukaan dimana daerah kaya oksigen menjadi katoda dan daerah miskin oksigen menjadi anoda.

Prinsip CP ialah mengubah semua daerah di permukaan logam menjadi katoda dengan cara menghubungkan anoda dari luar kepada logam yang dilindungi dan melewatkan arus listrik DC. Anoda luar bisa berupa anoda galvanik dimana arus yang mengalir adalah hasil dari perbedaan potensial dua logam, atau berupa anoda arus tanding (impressed current) dimana arus dialirkan dari sumber tenaga DC dari luar.

Dalam istilah elektrokimia, potensial listrik antara logam dan larutan elektrolit dibuat menjadi lebih negatif, dengan memberikan elektron (bermuatan negatif), ke sebuah nilai dimana reaksi korosi (anodik) tertahan dan hanya reaksi katodik yang berlangsung.

Jadi, CP dapat dicapai dengan dua cara (Gambar 3):

1. Dengan anoda galvanik (korban), "Sacrificial Anode Cathodic Protection" (SACP)

2. Dengan arus tanding/luar, "Impressed Current Cathodic Protection" (ICCP)
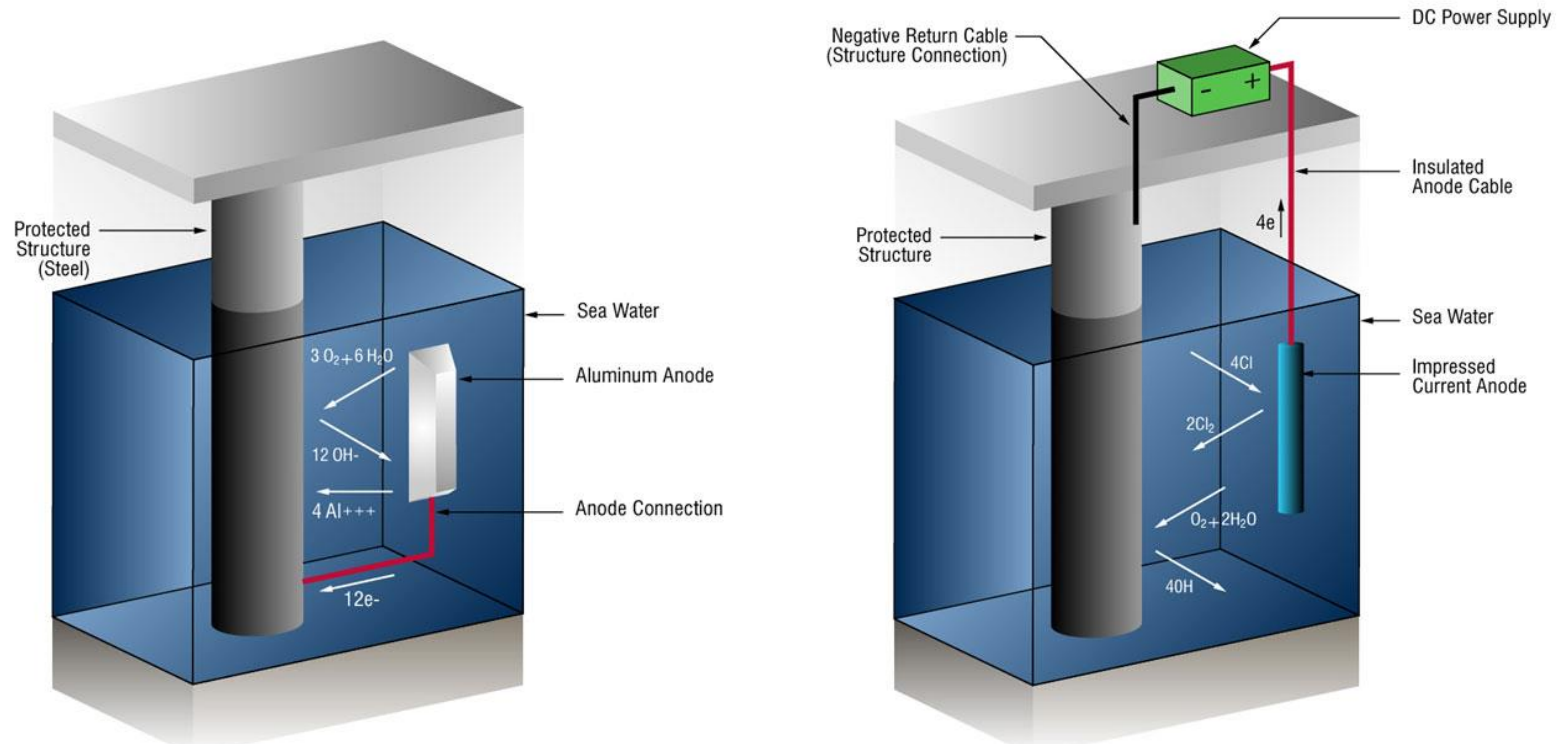

Gambar 3. Skema sistim CP: SACP (kiri); dan ICCP (kanan). Sumber: Deepwater Corrosion Services Ltd.

SACP menggunakan logam reaktif sebagai anoda luar yang dihubungkan secara elektrik kepada baja yang dilindungi. Perbedaan potensial alamiah antara anoda dan baja, seperti diindikasikan dengan posisi relatif mereka dalam deret galvanik, menyebabkan arus positif mengalir dari anoda kedalam elektrolit lalu ke baja. Akibatnya semua permukaan baja menjadi bermuatan lebih negatif dan menjadi katoda. Logam reaktif yang umum digunakan sebagai anoda korban adalah aluminium (Al), seng ( $\mathrm{Zn}$ ) dan magnesium (Mg). Logam-logam ini kemudian dipadu dengan unsur lain untuk meningkatkan performa jangka panjang dan karakteristik pelarutannya. 
ICCP menggunakan anoda inert (pelarutan nol atau rendah) dan sumber tenaga DC luar (AC yang disearahkan, rectified) untuk mengalirkan arus dari anoda luar ke permukaan katoda (baja) (Gambar 3). Anoda yang digunakan dapat berupa besi cor berkadar silikon (Si) tinggi, grafit, atau titanium (Ti).

\section{Keunggulan $\mathrm{CP}$}

Keunggulan utama CP dibanding teknik pengendalian korosi lainnya adalah kesederhanaan aplikasi yang hanya melibatkan pemeliharaan sebuah sirkit DC dan efektifitasnya dapat dimonitor terus menerus. CP sangat umum diterapkan pada struktur yang dilapis (coated) untuk mengendalikan korosi di daerah dimana lapisan tak berfungsi (cacat). CP juga dapat diterapkan kepada struktur yang sudah beroperasi untuk memperpanjang usia pakainya.

Penentuan CP sejak awal dapat menghindari pemberian alokasi korosi (corrosion allowance) kepada struktur berdinding tipis (seperti pipa) yang membuat ongkos produksi meningkat. Dia juga dapat diterapkan untuk menjamin keamanan ketika kebocoran kecil tidak bisa ditoleransi demi alasan keselamatan atau lingkungan.

Secara prinsip, CP dapat diterapkan ke semua struktur logam yang berada dalam elektrolit (air, tanah, bahkan beton). Dalam prakteknya, penerapan utama CP adalah untuk melindungi struktur baja yang terkubur di tanah atau tercelup di air. CP tidak dapat digunakan untuk mencegah korosi atmosfir. Tetapi dia dapat melindungi struktur beton bertulang yang terpapar ke atmosfir dan terkubur dalam tanah karena beton sendiri mengandung uap air yang cukup untuk bertindak sebagai elektrolit.

Struktur yang umum dilindungi dengan CP adalah permukaan luar dari: jaringan pipa, lambung kapal, dasar tangki, jeti dan struktur pelabuhan, pelat baja tubular dan tiang pondasi, anjungan lepas pantai, struktur terapung dan tenggelam.

CP juga dapat melindungi pemukaan dalam dari: pipa berdiameter besar, tangki kapal, tangki penyimpanan dan sistim sirkulasi air. Namun karena anoda internal jarang mampu menyebarkan arus proteksi untuk jarak lebih dari 5 kali diameter, CP umumnya tidak praktis atau tidak cocok untuk pipa berdiameter kecil.

CP dapat diterapkan untuk mengendalikan korosi dari baja dalam struktur beton bertulang seperti dalam jembatan dan bangunan pelabuhan. CP juga dapat diterapkan untuk paduan berbasis $\mathrm{Cu}$ dalam sistim air minum, untuk kabel dan paduan Al tetapi dengan kontrol yang ketat.

\section{Keperluan dasar CP}

Syarat paling penting dari CP adalah logam yang dilindungi terpapar dalam elektrolit. Untuk masing-masing sistim $\mathrm{CP}$, keperluan dasarnya adalah:

\section{SACP:}

1. Anoda korban,

2. Kontak langsung (lasan) antara anoda, konduktor dan struktur,

3. Koneksi yang aman dan hambatan yang minimum antara konduktor ke struktur dan konduktor ke anoda. 
ICCP:

1. Anoda inert (tunggal atau kluster yang terkoneksi dalam backfill, atau biasa disebut groundbed),

2. Sumber tenaga DC (transformer-rectifier, TR),

3. Konduktor yang terisolasi dengan baik, hambatan yang minimum dan koneksi yang aman antara anoda dan sumber tenaga,

4. Koneksi yang aman dan hambatan yang minimum antara sumber tenaga ke struktur.

Untuk keduanya, keputusan disain dasar harus dibuat untuk memilih jenis sistim dan jenis anoda paling cocok untuk sistim itu. Juga diperlukan penentuan ukuran dan jumlah sumber tenaga atau anoda korban dan distribusinya kepada struktur.

Keperluan lain yang harus dipenuhi untuk menjamin CP diterapkan secara lebih ekonomis dan handal adalah:

a. Kesinambungan listrik. Hambatan dari konduktor dan struktur harus meminimalkan penurunan potensial (IR drop) dari arus proteksi yang kembali ke struktur.

b. Pelapisan (coating). Adanya lapisan pelindung/isolasi pada struktur akan sangat menurunkan keperluan arus CP dari permukaan logam yang dilindungi. Penggunaan lapisan yang sesuai dan baik meningkatkan efektifitas sebaran arus CP. Kombinasi dari pelapisan dan CP umumnya akan menghasilkan sistim perlindungan yang paling praktis dan ekonomis. Pelapisan yang ideal memiliki tahanan listrik tinggi, kontinuitas dan ikatan yang kuat ke permukaan logam. Karakteristik lain yang diharapkan adalah stabilitas dalam lingkungan, ketahanan abrasi dan kesesuaian dengan lingkungan basa yang diciptakan atau ditingkatkan oleh CP.

c. Isolasi struktur. Seringkali penyebaran arus CP perlu dibatasi. Untuk pipa dan tangki, hal ini dapat dicapai dengan menyisipkan sambungan isolasi listrik monolithic pada struktur atau perangkat flen isolasi. Untuk mengisolasi sistim pembumian (grounding), kadang digunakan sel polarisasi, yang mampu menahan arus DC tegangan rendah CP tetapi melewatkan arus AC tegangan tinggi.

d. Fasilitas uji. Penting untuk memikirkan lokasi fasilitas uji, stasiun uji, kupon pemantauan korosi, elektroda pembanding permanen dan bagaimana data dapat dikumpulkan atau dilihat secara rutin.

\section{Faktor desain}

\subsection{Pertimbangan awal}

Modifikasi terhadap struktur untuk mengakomodasi keperluan CP akan lebih baik dilakukan di tahap awal disain dan tahap pra-konstruksi struktur tersebut. Kunjungan lapangan (survey) diperlukan untuk melihat lokasi atau rute struktur bawah tanah yang diajukan (misalnya jaringan pipa) dan untuk mendapat informasi tambahan tentang daerah dengan tahanan rendah, kesediaan tenaga listrik dan keberadaan arus dc liar (stray current) atau kemungkinan lainnya.

Survey biasanya dilakukan sebelum desain dibuat dan seringkali digabungkan dengan studi ekonomi untuk proposal CP. Sementara itu, data-data utama untuk disain juga dikumpulkan. Jika struktur sudah ada (struktur lama), penting untuk mengukur potensial antara struktur dan tanah dan untuk mendapatkan informasi daerah mana yang anodik dan mana yang katodik. Sebagai 
tambahan, pemasangan CP sementara dapat membantu perhitungan keperluan arus yang lebih akurat dan gambaran penyebarannya terhadap struktur yang dinilai.

Disain CP untuk struktur baru harus melibatkan perhitungan: keperluan arus, tahanan anoda terhadap tanah, jumlah dan lokasi anoda atau groundbed, keperluan listrik dan fasilitas uji dan pemantauan. Demikian juga spesifikasi proyek dan standar yang berlaku perlu diacu. Untuk kasus jaringan pipa tanah (onshore), negosiasi dengan pemilik tanah, otoritas publik dan pihak terkait lainnya harus dilakukan dalam tahap disain untuk kemudahan konstruksi groundbed, rute kabel, lokasi TR dan penyediaan listrik.

\subsection{Kriteria $\mathrm{CP}$, potensial dan penyebarannya}

Dalam praktek, potensial antara struktur dan elektrolit diukur menggunakan elektroda rujukan (reference electrode atau half-cell). Contoh elektroda rujukan paling umum dipakai adalah $\mathrm{Cu}$ $\mathrm{CuSO}_{4}$ (CSE). Kriteria proteksi umum untuk baja di elektrolit aerob dengan keasaman $(\mathrm{pH})$ netral adalah lebih negatif dari -850 mV (CSE). Ketika terpapar kepada bakteri anaerob, seperti sulphate-reducing bacteria (SBR), baja memerlukan potensial lebih negatif dari $\mathbf{- 9 5 0} \mathbf{~ m V}$ (CSE). Idealnya, elektroda rujukan ditempatkan sangat dekat dengan permukaan baja yang diukur untuk memperoleh tingkat akurasi tinggi dan mengurangi kesalahan pengukuran.

Nilai potensial terukur pada struktur yang di-CP tergantung kepada reaksi anodik-katodik, geometri struktur dan tahanan listrik internal. Namun, lapisan pelindung lah yang paling besar pengaruhnya terhadap potensial untuk setiap arus yang diberikan.

Potensial umumnya akan lebih negatif pada titik dekat dengan anoda atau groundbed, dan untuk jaringan pipa, akan melemah menuju potensial alamiah korosi seiring jarak menjauhi groundbed. Sebagai contoh, untuk kasus ICCP, sebuah instalasi CP tunggal dapat melindungi jaringan pipa yang terlapis baik sejauh $150 \mathrm{~km}$. Namun untuk pipa yang sama tetapi tidak dilapis lindung (telanjang) mungkin diperlukan instalasi pada interval setiap $2 \mathrm{~km}$.

\subsection{Masalah yang harus diatasi}

Ada beberapa keterbatasan pada penggunakan CP. Kelebihan potensial negatif dapat mempercepat korosi pada struktur Al karena terciptanya lingkungan basa di katoda. Lingkungan basa ini dapat juga merusak jenis pelapisan tertentu dan menyebabkan penurunan adesinya. Evolusi hidrogen di permukaan katoda juga dapat menyebabkan penggetasan hidrogen dan penurunan kekuatan pada baja berkekuatan tinggi (high strength steels) yang dapat mengarah pada kegagalan struktur. Pembentukan gas hidrogen juga dapat menyebabkan pelepasan lapisan (disbondment) yang bisa membuat lapisan bertindak sebagai perisai isolasi terhadap arus CP.

CP dapat menimbulkan bahaya percikan listrik akibat arus yang mengalir di struktur yang berada di daerah berbahaya (misalnya mudah terbakar). Umumnya SACP tidak akan menyebabkan masalah ini karena kemampuan atur dirinya (self regulating). Dia bahkan sering dianggap sistim yang pasang dan lupakan (fit and forget), meski tetap harus diinspeksi teratur untuk menjamin keperluan arus terpenuhi.

Setiap struktur kedua (asing) yang berada dalam elektrolit yang sama dapat menerima dan melepas arus CP dengan bertindak sebagai jalur alternatif bertahanan rendah. Korosi akan terakselerasi di struktur kedua di setiap titik dimana arus keluar. Fenomena ini disebut korosi arus liar (stray current corrosion). Interaksi ini dapat terjadi misalnya pada kapal yang sandar sekitar jeti yang dilindungi CP, atau pada pipa yang melintangi pipa yang dilindungi CP. Interaksi ini dapat diminimalkan melalui disain CP yang berhati-hati. Khususnya dengan mengoperasikan 
rapat arus sekecil mungkin dan dengan menjaga jarak aman antara struktur yang dilindungi dengan struktur kedua, dan antara anoda atau groundbed dengan struktur kedua tersebut.

Dalam hal ini, SACP lebih unggul karena tidak menciptakan masalah interaksi dan sangat disukai untuk pelindungan struktur di daerah padat dan lokasi yang kompleks. Namun, prosedur dan metoda untuk menyelesaikan masalah interaksi telah tersedia dan pengujian seharusnya dilakukan dengan kehadiran semua pihak yang terlibat sehingga pilihan penyelesaian dapat disetujui atau batasan interaksi yang dapat diterima bisa ditentukan bersama.

\subsection{Peralatan $\mathbf{C P}$}

Variasi anoda galvanik dari paduan $\mathrm{Mg}$, Al atau $\mathrm{Zn}$ tersedia di pasaran dalam berbagai bentuk; blok, batang atau kawat. Paduan ini dicor dengan insersi baja untuk pemasangan dan untuk memelihara kesinambungan listrik dan kekuatan mekanik menuju akhir umur anoda. Insert dapat langsung dilas atau dibaut ke struktur yang dilindungi, atau anoda dapat dihubungkan dengan kabel (umumnya $\mathrm{Cu}$ ) seperti untuk jaringan pipa.

Groundbed untuk ICCP umumnya terbuat dari besi cor berkadar Si tinggi. Namun sekarang anoda campuran oksida logam (mixed metal oxides, MMO) makin popular untuk semua lingkungan karena keunggulan karakteristik mekanik dan listriknya dan ukurannya yang kompak. Untuk aplikasi air laut dimana ion khlorida hadir, anoda MMO berfungsi baik demikian juga besi cor berkadar Si tinggi yang dipadu dengan khromium ( $\mathrm{Cr}$ ). Anoda lain adalah paduan Ti atau niobium $(\mathrm{Nb})$ yang dilapis tipis dengan platina $(\mathrm{Pt})$.

Banyak pilihan untuk sumber tenaga DC, namun yang paling populer adalah plat selenium (Se) atau rectifier diode Si dengan unit transformer (TR) yang dihubungkan dengan jaringan AC yang tersedia atau generator diesel atau gas. Untuk banyak aplikasi, umumnya dipakai sistim dengan tegangan DC atau arus yang konstan.

Di daerah terpencil, sumber tenaga dapat berupa generator thermo-electric, turbin uap dan generator surya atau angin. Pilihan tentunya tergantung pada keperluan tenaga, kemampuan pemeliharaan dan kondisi lingkungan. Tersedia juga unit kontrol otomatis yang mampu mengatur keluaran arus sesuai perubahan potensial yang terukur oleh elektroda permanen.

\subsection{Pertimbangan ekonomi}

Pada tahap disain, pilihan harus tentukan antara SACP atau ICCP. Dalam keadaan tertentu, keduanya mungkin bisa dipakai bersamaan, tetapi interaksi antara keduanya harus dihindari.

SACP memiliki keunggulan dalam hal: mudah dipasang; tidak tergantung pada sumber tenaga listrik luar; cocok untuk proteksi setempat; dan tidak terlalu mempengaruhi struktur lain disekitarnya. Namun, keluaran arus dari ukuran dan berat anoda galvanik komersial adalah relatif kecil dan sangat tergantung pada resistivitas listrik dari elektrolit (tanah, air atau beton). Karenanya, anoda Al dan Zn, yang memiliki potensial dorong sekitar $500 \mathrm{mV}$, terbatas untuk penggunaan di elektrolit yang memiliki resistivitas kurang dari 5 Ohm.m.

Anoda galvanik umumnya mampu mengatur diri karena keluaran arus biasanya lebih kecil dari kemampuan arus keluaran maksimumnya dan diatur oleh perbedaan potensial antara dia dan logam struktur. Arus dari anoda umumnya tidak dapat dikontrol; sehingga ketika ada perubahan di struktur, misalnya penurunan kualitas pelapisan yang membuat keperluan arus meningkat, akan diperlukan penambahan anoda baru untuk mempertahankan CP. 


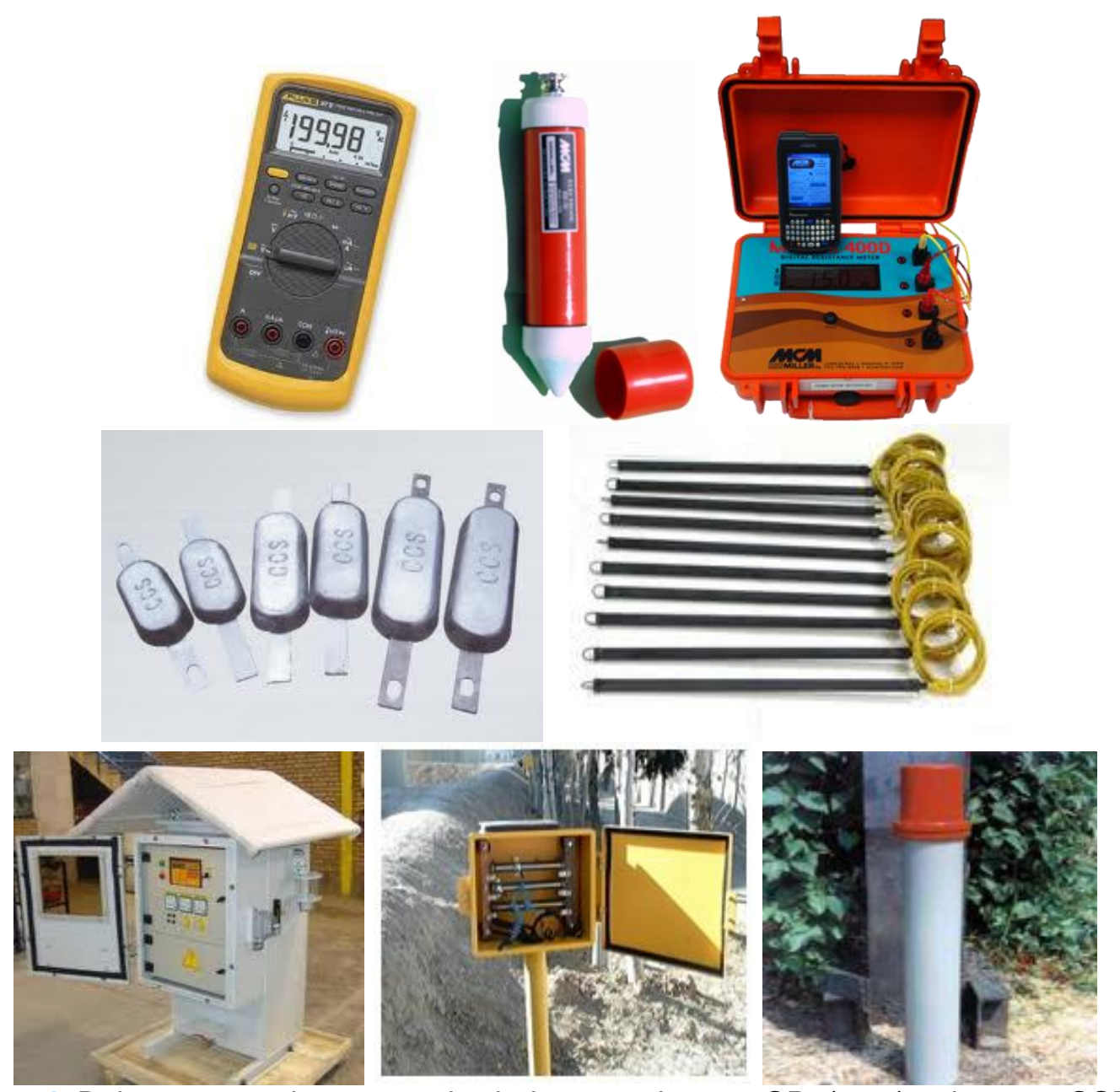

Gambar 4. Beberapa peralatan yang berhubungan dengan CP: (atas) voltmeter, CSE, soil resistance meter; (tengah) Mg anode, MMO anode; (bawah) TR, junction box, test point.

Pemasangan ICCP memiliki keunggulan karena mampu: menyediakan arus yang relatif besar; menyediakan tegangan dorong DC yang besar (sampai $50 \mathrm{~V}$ ) dan memungkinkan untuk diterapkan di semua jenis elektrolit; dan menyediakan keluaran arus yang fleksibel dan mampu mengakomodasi perubahan pada struktur yang dilindungi. Namun, umumnya kehati-hatian harus diperhatikan dalam disain untuk meminimalkan interaksi dengan struktur lain, atau ketika tidak tersedia sumber AC harus dicari alternatif lain seperti tenaga surya, diesel, dsb. ICCP juga memerlukan pemeliharaan dan pemantauan yang teratur.

Umumnya, SACP lebih disukai untuk struktur yang kecil dan terlapis baik, perlu arus rendah atau untuk perlindungan setempat (lokal). ICCP lebih dipakai untuk struktur besar yang kompleks yang mungkin tanpa atau terlapis lindung kurang baik.

Namun demikian, di pekerjaan lepas pantai Laut Utara ditemukan bahwa SACP terbukti lebih ekonomis untuk anjungan besar tak telapis lindung karena biaya awal untuk pelapisan dan pemeliharan sangat tinggi. SACP juga sangat mudah dipasang dan tidak tergantung dari sumber tenaga sehingga mampu memberikan perlindungan seketika untuk struktur terapung. 


\section{Pengawasan dan pemeliharaan}

Sistim CP dapat diawasi (monitor) secara efektif dengan megukur potensial antara struktur dan elektrolit menggunakan high input impedance voltmeter dan elektroda standar yang sesuai. Elektroda standar praktis adalah $\mathrm{CSE}, \mathrm{Ag}-\mathrm{AgCl}$ atau $\mathrm{Ag}-\mathrm{KCl}$ dan $\mathrm{Zn}$. Untuk jaringan pipa bawah tanah akan diperlukan survey untuk mengetahui profil potensial sepanjang rute pipa termasuk interaksi dengan struktur asing. Kini pekerjaan ini terbantu dengan metoda survey potensial interval jarak dekat (Close-interval Potential Survey, CIPS), yang biasa dilakukan bersamaan dengan pengukuran gradien tegangan (DC Voltage Gradient, DCVG) untuk mengetahui cacat pelapisan (Gambar 5).

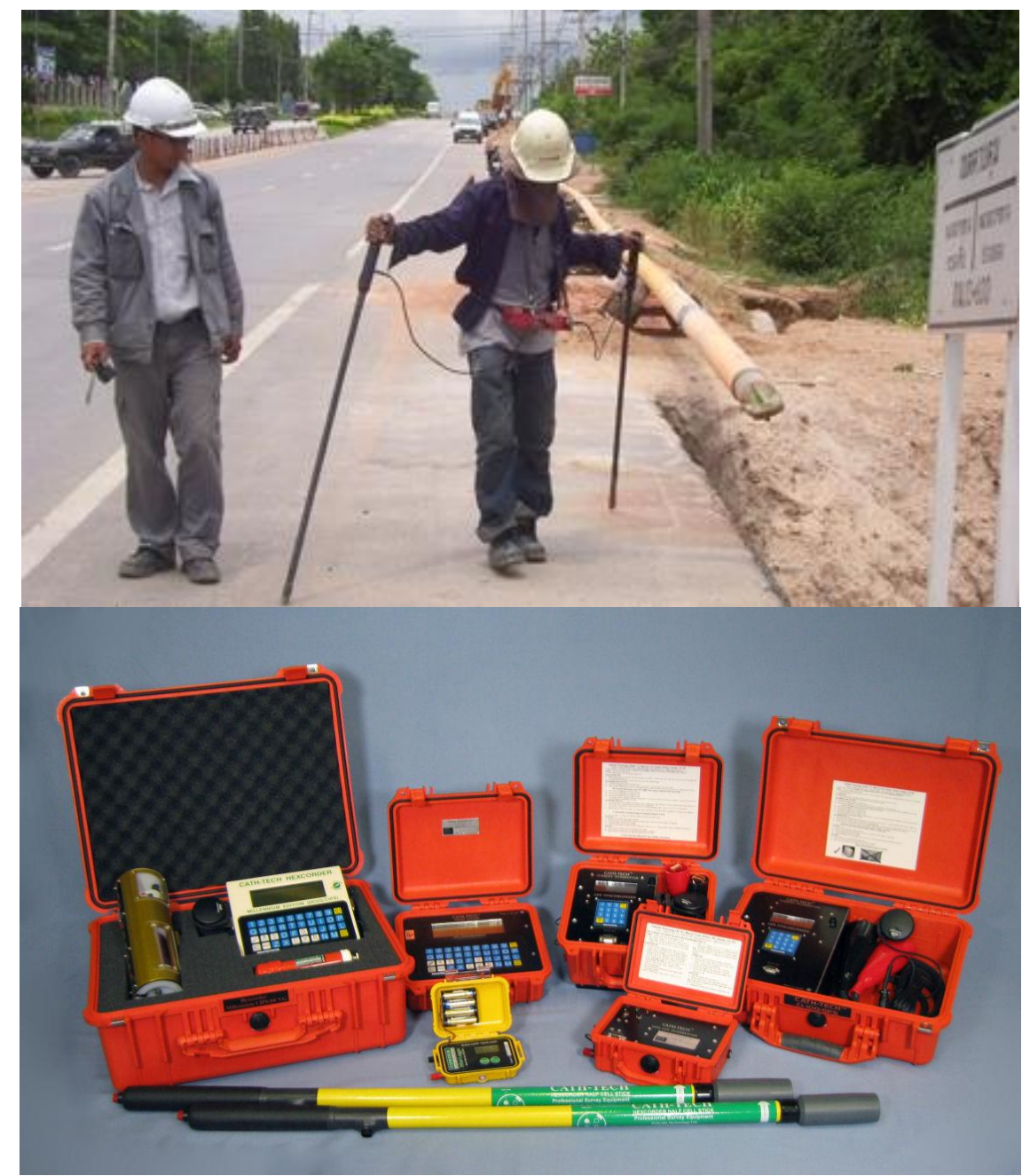

Gambar 5. Survey potensial interval jarak dekat (atas); peralatan CIPS dan DCVG (bawah). Sumber: CPE Engineering, Thailand dan MCM McMiller Co., US.

Hasil survey akan menentukan seberapa jauh keluaran arus CP harus disesuaikan untuk menjamin potensial perlindungan terpelihara pada tingkat negatif yang sesuai dengan spesifikasi proyek. Tingkat perlindungan untuk baja di tanah atau air adalah pada potensial lebih negatif dari $-850 \mathrm{mV}(\mathrm{CSE})$ atau $-800 \mathrm{mV}(\mathrm{Ag}-\mathrm{AgCl}$ air laut).

Keluaran TR dapat disajikan secara telemetri di stasiun pusat kontrol. Sekarang makin banyak sistim CP yang dikendalikan dan diawasi dengan komputer melalui hubungan modem secara 
jarak jauh. Sistim komunikasi lain yang ada misalnya pengawasan potensial pipa ke tanah dengan helikopter atau pesawat ringan. Keluaran anoda SACP juga dapat diawasi, misalnya arus dalam sambungan listrik antara struktur. Sementara pengujian untuk mengetahui adanya interaksi umumnya dilakukan pertahun ketika wilayah tertentu berada dalam resiko atau setelah dilakukan penyesuain keluaran arus $\mathrm{CP}$.

Pemeliharaan termasuk pemeliharan mekanik dari peralatan sumber tenaga dan pemeliharaan permukaan (cat) peralatan tersebut. Merupakan praktek yang baik untuk memberitahukan semua pemilik sistim CP dan infrastruktur di daerah yang dipengaruhi tentang adanya sistim CP baru atau perubahan signifikan terhadap sistim yang ada sehingga pengaruh dari fasilitas ini dapat dinilai.

\section{Sumber informasi dan konsultasi CP}

\subsection{Organisasi Korosi}

Asosiasi Korosi Indonesia (Indonesian Corrosion Association, Indocor)

Jalan Waspada No. 3 Bandung

Telepon: +62-22-70820554; Fax: +62-22-2041953

Email: indocor@cbn.net.id; website: www.indocor.org

NACE International

1440 South Creek Drive, Houston, USA

Phone: +1 281-228-6223 or +1 800-797-6223; Fax: +1 281-228-6300

Email: firstservice@nace.org; website: www.nace.org

The Institute of Corrosion (ICorr)

The Newton Building, St George's Avenue, Northampton, UK

Tel: + 44 (0)1604 893883; Fax: + 44 (0)1604 893878

Email: admin@icorr.org; website: www.icorr.org

\subsection{Contoh standar yang berkaitan dengan $\mathrm{CP}$}

NACE:

- SP0169-2007 (formerly RP0169), Control of External Corrosion on Underground or Submerged Metallic Piping Systems.

- SP0186-2007 (formerly RP0186), Application of Cathodic Protection for External Surfaces of Steel Well Casings.

- SP0285-2011 (formerly RP0285), Corrosion Control of Underground Storage Tank Systems by Cathodic Protection.

Keterangan lebih lanjut: http://www.nace.org/standards/

\section{British Standard:}

- BS EN 12954, Cathodic protection of buried or immersed metallic structures - General principles and application for pipelines.

- BS EN 12474, Cathodic protection for submarine pipelines.

- BS EN 12473, General principles of cathodic protection in sea water.

Keterangan lebih lanjut: http://www.bsigroup.com/en/Standards-and-Publications/ 
ISO:

- ISO 12473:2006, General principles of cathodic protection in sea water.

- ISO 12696:2012, Cathodic protection of steel in concrete.

- ISO/DIS 13174, Cathodic protection of harbour installations.

Keterangan lebih lanjut: http://www.iso.org/iso/home/store/catalogue ics.htm

DNV:

- DNV-RP-B401, Cathodic Protection Design.

- DNV-RP-F103, Cathodic Protection of Submarine Pipelines by Galvanic Anodes.

- DNV-RP-F112, Design of Duplex Stainless Steel Subsea Equipment Exposed to Cathodic Protection.

Keterangan lebih lanjut: http://exchange.dnv.com/publishing/codes/toc edition.asp

\subsection{Pelatihan dan sertifikasi CP \\ Indocor: \\ - CP Level-1 ( technician) \\ - CP Level-2 ( technologist) \\ Keterangan lebih lanjut: http://indocor.org/}

NACE:

- CP Level-1 (tester)

- CP Level-2 (technician)

- CP Level-3 (technologist)

- CP Level-4 (specialist)

Keterangan lebih lanjut: https://www.nace.org/education/courses-by-program/cathodic-protection

ICorr:

- CP Level-1 (technician)

- CP Level-2 (senior technician)

- CP Level-3 (senior engineer)

Keterangan lebih lanjut: https://www.icorr.org/cathodic-protection-training/

\section{Sumber rujukan}

[1] R.L. Kean and K. G. Davies, Cathodic Protection, DTI Publication. Available online at: www.npl.co.uk

[2] Peabody's Control of Pipeline Corrosion. (2 ${ }^{\text {nd }}$ edition, Ed by R Bianchetti), NACE, Houston, 2000.

[3] R. Baboian, NACE Corrosion Engineer's Reference Book, NACE, Houston, 2002.

Hendra Hermawan adalah dosen di departemen teknik pertambangan, metalurgi dan material, Laval University, Kanada. Menyelesaikan pendidikan S1 dan S2 di Teknik Material ITB dan S3 di Laval University. Bersertifikat Chartered Engineer dari Engineering Council, Inggris dan Cathodic Protection Level-2 dari NACE International. Berpengalaman dalam beberapa proyek yang berkaitan dengan material dan korosi sejak pertama bekerja untuk PT. Tripatra Engineering dan beberapa perusahan lain di dalam dan luar negeri. 